\title{
Digital Marketing in the System of Promotion of Organic Products
}

\section{IRYNA NOVYTSKA ${ }^{1}$, IRYNA CHYCHKALO-KONDRATSKA ${ }^{2}$, MARYNA CHYZHEVSKA ${ }^{3}$, HANNA SYDORENKO-MELNYK ${ }^{4}$, LIUBOV TYTARENKO 5}

\author{
${ }^{1}$ Educational and Research Institute of Finance, Economics and Management \\ National University "Yuri Kondratyuk Poltava polytechnic", UKRAINE \\ ${ }^{2}$ Department of International Economic Relations and Tourism, Economics and Management \\ National University "Yuri Kondratyuk Poltava polytechnic", UKRAINE \\ ${ }^{3}$ Department of Economic Theory and Economic Cybernetics, National University "Yuri Kondratyuk \\ Poltava polytechnic", UKRAINE \\ ${ }^{4}$ Department of Finance and Banking, Poltava University of Economics and Trade, UKRAINE \\ ${ }^{5}$ Department of International Economic Relations and Tourism, National University "Yuri \\ Kondratyuk Poltava polytechnic", UKRAINE
}

\begin{abstract}
The availability of digital technologies for a wide variety of companies opens up fundamentally new opportunities for the collection and analysis of information about markets and consumers, the implementation of marketing communications with customers and the formation of brand awareness. Digital marketing provides interaction with customers and business partners using digital information and communication technologies and electronic means. The purpose of the research is to study the features of digital marketing in the sphere of promotion of organic products based on the investigation of the experience of European Union's countries. Design/Methodology/Approach: economic and statistical analysis and comparison; economic and mathematical method; formalization; analysis and synthesis; historical and logical methods; generalization. As a result of the study, it has been established that the development of digital marketing in the sphere of promoting organic products is in its infancy. It depends on the structure of producers, which is formed according to the principle of family farms or small farm enterprises with no more than 15 employees without a special position of a marketer. It has been proved that social networks are the main channels of digital marketing of enterprises - producers of organic products, forasmuch as they do not require additional costs to attract a specialist on marketing.
\end{abstract}

Key-Words: - Digital Marketing, E-commerce, Organic Products, Social Media, Marketplace, Family Farms, Farm Enterprises.

Received: October 16, 202. Revised: February 21, 2021. Accepted: February 28, 2021. Published: March 5, 2021.

\section{Introduction}

The development of the consumer economy over the last century has created several important problems that threaten human life. After all, the excessive exploitation of nature, the introduction of pesticides and growth stimulants in order to stimulate the development of agriculture has a detrimental effect on the environment, the quality of water resources. Herewith, excessive exploitation of soils and production of various foodstuffs did not solve the problem of hunger and malnutrition. Consequently, the world community was faced with the issue of taking measures to immediately stop soil degradation, ensure water quality and maintain public health through the formation of new approaches to farming and agriculture in general.

The development of organic farming is one of these approaches. After all, the production of organic products, on the one hand, improves the condition of soils and increases their fertility, and on the other hand, contributes to human health.

Despite the fact that organic farming is actively developing on a global scale, a wide variety of inhabitants of our planet are not very familiar with the beneficial properties of organic products. This fact is crucial for raising the issue of attracting digital marketing in order to promote such products in consumer market in the era of digital economy.

The purpose of the research is a follows: studying the features of digital marketing in the 
sphere of promoting organic products based on an analysis of the directions of its implementation in the countries of European Union, as well as the development of practical recommendations concerning improving the efficiency of using digital marketing channels for popularization of production and consumption of organic products.

The research objectives are as follows:

1. To identify trends in development of digital marketing and e-commerce in European Union.

2. To outline the problematic aspects of digital marketing at the level of small business enterprises and family farms in European Union.

3. To consider opportunities in order to increase the effectiveness of digital marketing at the level of small enterprises and family farms in European Union.

\section{Literature Review}

Investigation on the issues and trends of digital marketing in the system of promoting organic products is quite a challenge. On the one hand, it is due to the combination of four elements of the study object, namely: digital marketing - ecommerce - organic products - agriculture, and on the other hand - due to the lack of sufficient data for empirical economic and statistical analysis. At the same time, the growing trends in the development of both digital marketing and organic production are of great scientific interest to scientists from different countries towards covering the theoretical and methodological problems of digital marketing in agriculture, in general, and organic production, in particular.

Given the trends in the rapid development of Internet technologies, most researchers adhere to an opinion that the concept of digital marketing is identical to the concept of Internet marketing. Banerjee [1] believes that the term digital marketing includes all activities that are designed and developed in business through the Internet in order to identify, attract, win and achieve customers' loyalty. The same opinion is held by Bala \& Verma [2], Grubor A. \& Jaksa O. [3], Sturienè U. [4].

Kannan and $\mathrm{Li}$ [5] believe that digital marketing is an adaptive process that uses digital technology in order to create new value in new digital environments. Digital technologies enable entities to create such value both for themselves and for their customers thanks to customers' new experiences and interactions between them. Digital marketing itself is provided by a number of adaptive components that cover marketing activities, institutions, processes and customers.

We share the opinion of Kannan and Li [5] on the adaptability of the digital marketing process, forasmuch as the rapid development of digital and Internet technologies require constant adaptation of business and its customers to new realities and new methods of market research, behavioristic behavior and individual customers' needs. The adaptability of digital marketing in order to meet the individual needs of the customer through studying his behavior on social media or when using the websites of companies, in our opinion, is one of the distinguishing features of digital marketing from traditional one.

In the study of digital marketing, Durai \& King [6] focus not only on the process of attracting new customers and maintaining their loyalty, but also on increasing sales through digital channels, mainly through Internet technologies. Selling goods over the Internet closely links digital marketing with ecommerce, which is understood as the process of buying and selling goods and services on the Internet. In addition to buying and selling goods, many people use the Internet as a source of information in order to compare prices or view the latest products before shopping online or in a traditional store. E-commerce, as a term, describes a change in the way companies do business on the Internet environment, the way they treat their customers and suppliers, as well as a change in views on marketing and logistics. In a general sense, e-commerce means doing business electronically on the Internet $[7 ; 8 ; 9]$.

The development of digital marketing and ecommerce is based on new trends in business and business innovations aimed at increasing sales through the study of customers' needs by applying Internet technologies. One of the fastest growing trends of the modern economy is the development of organic agriculture and the production of organic products.

For the first time at the international level, the issue of excessive consumption in conditions of depletion of natural resources, as well as the harmfulness of pesticides to the environment and soils were reflected in the report of the Club of Rome "Limits to Growth" [10]. Subsequently, organic farming has been considered in the context of sustainable development [11], namely: responsible consumption; conservation of terrestrial ecosystems; clean water and proper sanitation. Organic products are good for human health. They reduce the risk of obesity, childhood diseases, 
harmful effects on human health of pesticides, antibiotics and growth stimulants $[12 ; 13]$.

Effective application of digital marketing makes it posssible to promote the idea of the usefulness of consuming organic products. However, the issue of digital marketing in the context of the promotion of organic products has not actually been studied in the scientific literature, due to the low level of interest of marketers in the agricultural sector. On the one hand, the high level of state support for agriculture creates comfortable and stable conditions (given the stability of the purchase of agricultural raw materials) for agribusiness, and on the other hand - the main focus of marketing (both traditional and digital) is directed on food products manufactured by food industry enterprises [14].

\section{The Research Methods}

The following methods have been used in the course of the research, namely: economic and statistical analysis; economic and mathematical method; formalization; analysis and synthesis; historical and logical methods; generalization.

\section{Results of the Research}

Investigation on the development of digital marketing in the field of promotion of organic products is quite a difficult task given the limited digital data on the number of manufacturers and the use of digital marketing channels. The base of European Union is the most structured statistical base in the field of organic farming. European Union's organic market is growing dynamically and as of 2020 its capitalization has exceeded 50 billion euros. 250000 farms are engaged in organic production, and agricultural land under organic products exceeds 7,5\% of the total area of agricultural land in EU [15].

The interest of the population of European Union in the consumption of organic products can be analyzed by using such a digital marketing channel as Google search engine and its service Google Trends [16]. Scientists Choi \& Varian were among the first to use this technique. Based on the analysis of queries in the Google search engine for the brand of cars Ford, Chevrolet and Toyota, they predicted the dynamics of their sales for the following two weeks. That is, the methodology proves that the statistics of queries in Google correlates with the current level of business activity and can be used to analyze and predict sales volumes or the dynamics of certain macroeconomic trends [17].

We have chosen the search query "organic products" in the Google search engine, which includes organic food, searches with the prefix "bio" (organic) (for example, organic flour, organic chocolate, organic milk, etc.), organic meat, etc., that is, in fact, a complete set of organic ingredients. Based on the selected topic, we have analyzed the number of queries in Google Trends in ten countries of European Union with the largest area of agricultural land under organic production. Google Trends service generates a query index for a word or a topic based on an estimate of the number of queries for the selected time period, determining the maximum number of queries, which is equal to 100 and, from this point determines the percentage of queries in other periods. The results of the analysis are grouped in Table 1.

Table 1. Dynamics of the number of queries on Google on the topic of "organic products"

\begin{tabular}{|c|c|c|c|c|c|c|c|c|c|}
\hline Countries & 2012 & 2013 & 2014 & 2015 & 2016 & 2017 & 2018 & 2019 & \begin{tabular}{|c|} 
Correlation \\
coefficient
\end{tabular} \\
\hline Austria, the area of organic farming & 18,62 & 18,40 & 19,35 & 20,30 & 21,25 & 23,37 & 24,08 & 25,33 & \multirow[b]{2}{*}{0,9189} \\
\hline $\begin{array}{l}\text { Austria, average number of queries } \\
\text { on Google, } \%\end{array}$ & 4,83 & 5,92 & 7,67 & 7,08 & 11,50 & 64,58 & 69,75 & 59,00 & \\
\hline Estonia, the area of organic farming & 14,86 & 15,65 & 15,96 & 15,68 & 18,02 & 20,01 & 20,98 & 22,33 & \multirow[b]{2}{*}{$-0,4997$} \\
\hline $\begin{array}{l}\text { Estonia, average number of queries } \\
\text { on Google, } \%\end{array}$ & 22,17 & 17,33 & 32,67 & 27,25 & 34,42 & 16,83 & 10,08 & 18,58 & \\
\hline Sweden, the area of organic farming & 15,76 & 16,50 & 16,53 & 17,14 & 18,30 & 19,16 & 20,29 & 20,43 & \multirow[b]{2}{*}{$-0,2104$} \\
\hline $\begin{array}{l}\text { Sweden, average number of queries } \\
\text { on Google, } \%\end{array}$ & 39,50 & 54,75 & 80,92 & 71,50 & 70,83 & 54,50 & 50,75 & 49,33 & \\
\hline $\begin{array}{l}\text { Switzerland, the area of organic } \\
\text { farming }\end{array}$ & 11,57 & 12,19 & 12,73 & 12,91 & 13,40 & 14,37 & 15,40 & 16,27 & 0,8807 \\
\hline
\end{tabular}




\begin{tabular}{|c|c|c|c|c|c|c|c|c|c|}
\hline $\begin{array}{l}\text { Switzerland, average number of } \\
\text { queries on Google, } \%\end{array}$ & 9,17 & 8,75 & 10,50 & 10,50 & 14,42 & 64,83 & 70,33 & 58,00 & \\
\hline $\begin{array}{l}\text { The Czech Republic, area of organic } \\
\text { agriculture }\end{array}$ & 13,29 & 13,47 & 13,44 & 13,68 & 14,00 & 14,09 & 14,76 & 15,19 & \multirow{2}{*}{$-0,8006$} \\
\hline $\begin{array}{l}\text { The Czech Republic, average } \\
\text { number of queries on Google, } \%\end{array}$ & 63,67 & 52,08 & 56,17 & 37,67 & 43,08 & 48,42 & 39,75 & 32,50 & \\
\hline Italy, the area of organic agriculture & 9,30 & 10,60 & 10,91 & 11,79 & 13,99 & 14,67 & 15,17 & 15,16 & \multirow[b]{2}{*}{0,4992} \\
\hline $\begin{array}{l}\text { Italy, average number of queries on } \\
\text { Google, } \%\end{array}$ & 41,00 & 39,25 & 54,50 & 56,00 & 73,75 & 48,25 & 49,92 & 59,08 & \\
\hline $\begin{array}{l}\text { Latvia, the area of organic } \\
\text { agriculture }\end{array}$ & 10,63 & 9,89 & 10,86 & 12,29 & 13,42 & 13,92 & 14,47 & 14,79 & \multirow{2}{*}{$-0,7404$} \\
\hline $\begin{array}{l}\text { Latvia, average number of queries on } \\
\text { Google, } \%\end{array}$ & 26,83 & 25,83 & 28,58 & 20,50 & 25,42 & 16,42 & 12,75 & 21,42 & \\
\hline Finland, the area of organic farming & 8,65 & 9,07 & 9,29 & 9,91 & 10,47 & 11,41 & 13,09 & 13,48 & \multirow[b]{2}{*}{$-0,8984$} \\
\hline $\begin{array}{l}\text { Finland, average number of queries } \\
\text { on Google, } \%\end{array}$ & 45,83 & 44,08 & 38,92 & 40,08 & 43,17 & 29,25 & 25,08 & 29,50 & \\
\hline $\begin{array}{l}\text { Denmark, the area of organic } \\
\text { farming }\end{array}$ & 7,31 & 6,44 & 6,25 & 6,33 & 7,81 & 8,60 & 9,75 & 10,87 & \multirow{2}{*}{$-0,1596$} \\
\hline $\begin{array}{l}\text { Denmark, average number of queries } \\
\text { on Google, } \%\end{array}$ & 31,42 & 47,17 & 44,33 & 58,25 & 65,33 & 44,67 & 39,33 & 47,58 & \\
\hline Slovenia, the area of organic farming & 7,32 & 8,07 & 8,55 & 8,85 & 9,12 & 9,60 & 10,01 & 10,35 & \multirow[b]{2}{*}{$-0,0352$} \\
\hline $\begin{array}{l}\text { Slovenia, average number of queries } \\
\text { on Google, } \%\end{array}$ & 18,67 & 24,83 & 29,42 & 50,75 & 43,58 & 30,33 & 19,00 & 19,17 & \\
\hline
\end{tabular}

Source: compiled by the author based on Eurostat data [18]

However, not in all countries studied there is a positive correlation between the dynamics of the number of queries on Google on the topic of "organic products" and the dynamics of the area of organic farming. For instance, the number of inquiries in such countries as Estonia, Latvia, Finland, Slovenia is insignificant, which indicates a low level of penetration of digital marketing and a low level of interest in organic products in these countries, despite the fact that the area of organic farming is quite large.

A small number of requests may depend on the mental attitudes of the population of a country towards making purchases on the Internet. For instance, the share of Internet users in Estonia is $91 \%$, while the share of customers through ecommerce channels is only 69\%, and in Denmark,

where the number of requests is higher, this figure is $86 \%$ of $98 \%$ of Internet users. In Latvia, the share of Internet buyers in general is only 55\% of $84 \%$ of Internet users, which obviously affects the number of queries in Google on the topic "organic products".. However, manufacturing enterprises producing organic products can use other digital marketing channels (television, radio) through which they attract customers to stationary stores, supermarkets and markets.

E-commerce is one of the important channels of digital marketing; it makes it possible for companies producing organic products to use a variety of commercial Internet resources and social networks in order to sell and simultaneously promote their products.

In this context, it is worth paying attention to the structure of online purchases by residents of European Union (Figure 1). It shows that the purchase of food and foodstuff is not in great demand, as only $17 \%$ of buyers have bought food and foodstuff through e-commerce channels. 


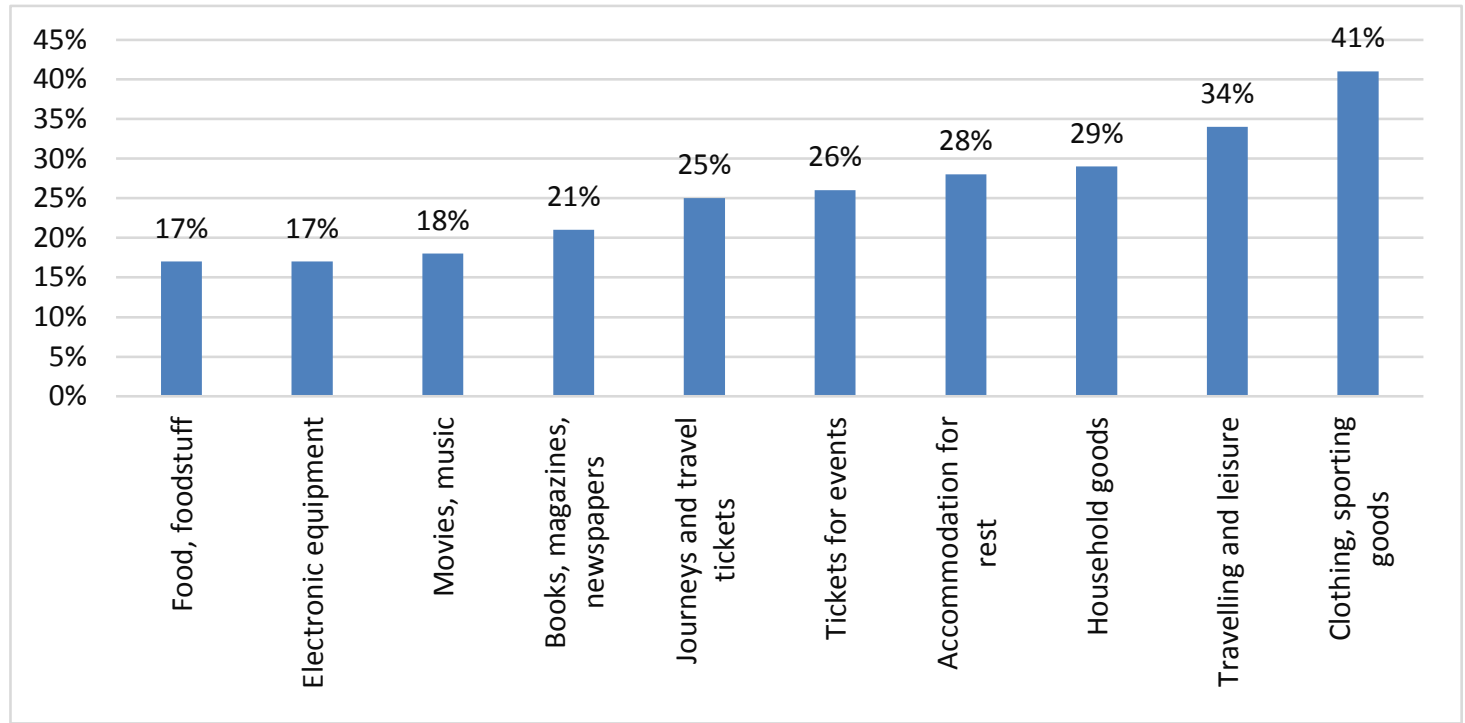

Figure 1. The structure of Internet purchases by the population of European Union Source: compiled by the author based on Eurostat data [15]

Taking into account the low demand for purchasing food products through e-commerce channels, it can be assumed that the demand for organic products on the Internet is also low. Such trends are quite objective, forasmuch as organic foods, due to the lack of various chemical additives, have a short shelf life; some of them can generally spoil quickly, which creates risks for consumers in the case of delivery of products by mail.

Nonetheless, digital marketing and e-commerce channels are relevant for other types of organic products that have an unlimited shelf life (toys, furniture, clothing, interior items) and can be sold through online stores. With regard to organic food, producers can use digital marketing channels to promote their brand, research the individual needs of potential customers, and through e-commerce to expand opportunities for pre-ordering products and selling them at points of delivery, which must be equipped with the necessary tools for long-term storage.

\section{Discussion}

Based on the conducted study of digital marketing in the sphere of promotion of organic products, it has been established that this issue is actually unexplored in the scientific literature. From our point of view, this is due to the insignificant development of the market for organic products, although in some countries the area under organic farming reaches $30-40 \%$ of the total area of agricultural land. It should be noted that the positive trends in the development of organic farming and the market for organic products will increase the interest of scientists in the study of digital marketing in this sphere.

Investigations in the sphere of marketing of the agricultural sector are focused on the studying traditional tools for marketing of food and organic products. Aigner et al. in their study pay attention to price incentives for the sale of organic products in large retail chains through the establishment of flexible price discounts. Along with this, the authors emphasize such important components of marketing organic products as the separation of competitive advantages of organic products over inorganic ones. The results of the present research can be adapted to digital marketing by taking the necessary measures in order to spread information about existing discounts and benefits of organic products to consumers through digital channels (social networks, television) [19].

The remarks of Dabbara and Chandrakumar M. are correct; the scholars believe that the underdevelopment of marketing in agriculture, in general, and digital marketing, in particular, is connected with an excessive government's intervention in the development of agricultural production, which is confirmed by the study [20]. After all, the high level of subsidies to the agricultural sector, including organic production, reduces the interest of organic producers in finding digital channels to promote products on the consumer market.

A key aspect of digital marketing in the sphere of promoting organic products is the structure of 
agriculture in most developed countries; it is scattered among small landowners who create family farms in Europe, and a ranch in the USA, which is an analog to family farms. Consequently, digital marketing at the level of family farms is based on one or two social media, which are used not for e-commerce, but to promote the image of the farm and its products. In this context, it is important to develop digital marketing at the state level, taking into account the need to increase the scale of organic farming in order to preserve soil quality and public health. In particular, the experience of Poland is considered as a positive one in the implementation of digital marketing for the promotion of organic products at the state level. A special website "Polish Basket" based on the type of online supermarket has been created in this country, where information on all organic products produced by Polish farmers has been collected. Along with this, online ordering and delivery of products to any region of the country is provided. The government of Poland through the National Center for Agricultural Support implements the program "Poland tastes good", where the means of digital marketing promote Polish dishes made from organic products [21]. Similar promotions are implemented in other European countries.

\section{Conclusions}

Based on the analysis of data on the use of digital marketing channels by small enterprises of European Union, the features of digital marketing for the promotion of organic products in the consumer market of Europe have been investigated. It has been substantiated that because of the limited structure of family farms, where less than 15 people work during the harvest season, organic producers are not able to form an effective digital marketing structure due to the lack of appropriate specialists in their staff and due to the lack of resources to attract the relevant specialist on marketing. It has been proved that social media and social networks are the basic channels of digital marketing for the promotion of organic products at the farm level; consequently, farms are able to advertise their products on their own.

Given the importance of organic products for solving social problems and achieving the goals of sustainable development, the need for the development of digital marketing at the state level has been substantiated in the article. After all, using e-government resources, the state is able to effectively disseminate information about the importance of organic farming and consumption of organic products. The state should form a culture of organic farming and organic consumption through digital marketing channels by using an individual approach to the client through targeted advertising in social media.

The practical significance of the present academic paper lies in forming a basis for research and analysis of digital marketing in the sphere of promotion of organic products, developing ways to improve the effectiveness of digital marketing at the level of organic producers, as well as at the state level.

The promising area of research in this context is studying the features of digital marketing at the level of specific family farms - producers of organic products from different European countries through interviews in order to gain more in-depth knowledge of the problematic aspects of using digital technologies towards promoting and selling products on the Internet. In addition, an important area of research may also be studying the role of state and public policy in the sphere of digital marketing of organic products.

\section{References:}

[1] Banerjee, A. (2016). Modern Trends and Practices of E-Marketing: An Overview, OSR Journal of Business and Management (IOSR-JBM), Special Issue, 16

[2] Bala, M, Verma, D. (2018). A Critical Review of Digital Marketing. International Journal of Management, IT \& Engineering, 8(10), 321-339.

[3] Grubor, A., Jaksa, O. (2018). Internet Marketing as a Business Necessity. Interdisciplinary Description of Complex Systems, 16, 265-274. DOI: 10.7906/indecs.16.2.6.

[4] Sturienè, U. (2019). Internet marketing tools. Vilnius University Open Series, 6774.

DOI:

10.15388/OpenSeries.2019.18406.

[5] Kannan, P., Li, H. (2017). Digital marketing: A framework, review and research agenda. International Journal of Research in Marketing, 34(1), 22-45.

[6] Durai, T., King, R. (2015). Impact of Digital Marketing on the Growth of Consumerism. SSRN Electronic Journal. DOI:10.2139/ssrn.3344421 
[7] Khan, A. (2016). Electronic Commerce: A Study on Benefits and Challenges in an Emerging Economy. Global Journal of Management and Business Research: $B$ Economics and Commerce, 16 (1). https://globaljournals.org/GJMBR_Volume 16/3-Electronic-Commerce-A-Study.pdf

[8] Lindsay, P. (2002), "E-commerce", The Economist Books. p. 1.

[9] Išoraitè, M., Miniotienè, N. (2018). Electronic Commerce: Theory and Practice. IJBE (Integrated Journal of Business and Economics), 2, 73. DOI:10.33019/ijbe.v2i2.78.

[10] Meadows, D. H., Meadows, D. L., Randers, J., Behrens, W. (1974). The Limits to Growth: A Report for the Club of Rome's Project on the Predicament of Mankind Paperback, January 1.

[11] The Global Goals. Retrieved from https://www.globalgoals.org/

[12] Glibowski, P. (2020). Organic food and health. Roczniki Panstwowego Zakladu Higieny. DOI: 10.32394/rpzh.2020.0110

[13] Piccolo, A. (2020). Organic Food Organic food yes or not. Austin Anthropol, 4 (1), 12. https://www.researchgate.net/publication/3 39788183_Organic_food_yes_or_not

[14] Chimhundu, R. (2018). Marketing Food Brands. DOI:10.1007/978-3-319-75832-9.

[15] Eurostat, (2021). E-commerce purchases. Retrieved from https://ec.europa.eu/eurostat/databrowser/vi ew/isoc_ec_ebuyn $2 /$ default/table?lang=en

[16] Google Trends, (2021). Retrieved from https://trends.google.com.ua/trends/?geo $=\mathrm{U}$ A.

[17] Choi, H., Varian, H. (2009). Predicting the Present with Google trends. Google Inc, 23.

https://static.googleusercontent.com/media/ www.google.com/uk//googleblogs/pdfs/go ogle_predicting_the_present.pdf
[18] Eurostat, (2021). Organic crop area by agricultural production methods and crops (from 2012 onwards). Retrieved from https://ec.europa.eu/eurostat/databrowser/vi ew/org_cropar/default/table?lang=en.

[19] Aigner, A., Wilken, R., Geisendorf, S. (2019). The Effectiveness of Promotional Cues for Organic Products in the German Retail Market. Sustainability, 11, DOI:10.3390/su11246986

[20] Dabbara, R., Chandrakumar, M. (2019). A Study on Digital Agricultural Marketing Services-A Detailed Review. Awareness on Digital apps used in India and in world for marketing of agriculture produce. Conference: Credit seminar Affiliation: Tamil Nadu Agricultural University. DOI: 10.13140/RG.2.2.33668.07049.

[21] Krajowy ośrodek wsparcia rolnictwa. Retrieved from https://www.kowr.gov.pl/

\section{Creative Commons Attribution License 4.0 (Attribution 4.0 International, CC BY 4.0)}

This article is published under the terms of the Creative Commons Attribution License 4.0

https://creativecommons.org/licenses/by/4.0/deed.en_US 